\title{
HUKUMAN KEBIRI TERHADAP PELAKU KEJAHATAN PEDOFILIA DALAM UNDANG-UNDANG NOMOR 17 TAHUN 2016 TENTANG PERLINDUNGAN ANAK
}

\author{
Muh. AL-Husaini \\ muhalhusaini119@gmail.com \\ Magister Ilmu Hukum Fakultas Hukum Universitas Mataram \\ Rodliyah \\ rodliyah@unram.ac.id \\ Magister Ilmu Hukum Fakultas Hukum Universitas Mataram
}

\author{
Any Suryani Hamzah \\ anysuryani@unram.ac.id \\ Magister Ilmu Hukum Fakultas Hukum Universitas Mataram
}

\begin{abstract}
Abstrak
Penelitian ini bertujuan untuk menganalisis bagaimana hukuman kebiri terhadap pelaku kejahatan pedofilia dalam perspektif HAM dan penerapan hukuman kebiri terhadap pelaku kejahatan pedofilia. Penelitian ini merupakan penelitian hukum normatif berdasarkan pertimbangan bahwa peneltian ini dalam analisis permasalahan dilakukan dengan cara memadukan bahan-bahan hukum primer dan sekunder. Pendekatan yang digunakan adalah pendekatan Perundang-Undangan (Satatute Approach), Pendekatan Konseptual (Konseptual Approach), Pendekatan perbandingan (Comparative Approach). Berdasarkan hasil penelitian dapat disimpulkan bahwa penegebirian kimia dapa dikualifikasi sebagai penghukuman yang keji dan tidak manusiawi yang demikian tidak sesuai dengan konvensi-konvensi internasional tentang HAM dan Konstitusi, penerapan hukuman tambahan kebiri kimia di Indonesia akan menemui berbagai hambatan, di antaranya hukuman kebiri kimia ini bertentangan dengan kode etik kedokteran yang ditunjuk sebagai eksekutor, dan hukuman kebiri kimia tidak tercantum dalam jenis hukuman tambahan dalam KUHP Indonesia.
\end{abstract}

Kata Kunci: Perlindungan anak, Kebiri, Hak Asasi Manusia 


\section{PENDAHULUAN}

Undang-undang perlindungan anak diundangkan dengan maksud untuk memberikan perlindungan kepada anak terhadap hak-haknya termasuk kaitannya dengan masalah pedofilia, sebab dalam undangundang tersebut secara umum menjamin terpenuhinya hak-hak anak agar dapat tumbuh, berkembang dan berpartisipasi optimal sesuai harkat dan martabat, serta mendapat perlindungan dari kekerasan. Undang-undang perlindungan anak juga mengatur tentang larangan terkait kekerasan seksual kepada anak, yaitu Pasal 76D mengatakan bahwa, "setiap orang dilarang melakukan kekerasan atau ancaman kekerasan memaksa anak melakukan persetubuhan dengannya atau dengan orang lain." Berdasarkan hal tersebut, kemudian diancam sanksi pidana yang diatur dalam Pasal 81 yang menyatakan bahwa "setiap orang yang melanggar ketentuan sebagaimana dimaksud dalam Pasal $76 \mathrm{D}$, dipidana dengan pidana penjara paling singkat 5 (lima) tahun dan paling lama 15 (lima belas) tahun dan/atau denda paling banyak Rp. 5.000.000.000 (lima milyar rupiah)." Sanksi ini akan bertambah $1 / 3$ (sepertiga) apabila tindak pidana dilakukan oleh orang tua, wali, pengasuh anak, pendidik atau tenaga kependidikan.

Telah diaturnya mengenai bentuk atau jenis hukuman atau sanksi kepada pelaku kejahatan seksual pada anak seperti yang dimuat dalam ketentuan umum yakni KUHP dan ketentuan khusus dalam undangundang perlindungan anak tidak membuat jera pelaku tindak pidana dan masyarakat yang dalam hal ini pelaku potensial, yang mana hal ini ditandai dengan maraknya kejahatan atau tindak pidana kejahatan seksual pada anak. Berdasarkan fakta yang ada saat ini, undang-undang perlindungan anak belum dapat memberikan jaminan kepada anakanak terhadap tindak pidana kekerasan seksual. Saat ini kekerasan pada anak semakin meningkat dari tahun ke tahun, yaitu berdasarkan data yang dihimpun oleh Pusat Data dan Informasi (Pusdatin) Komnas Anak dalam kurun waktu 2010-2015, yang menerima pengaduan pada tahun 2010 sebanyak 2.046, dimana $42 \%$ diantaranya merupakan kejahatan seksual. Pada tahun 2011 menjadi 2.426 kasus, yang $52 \%$ kejahatan seksual. Sementara pada 2012 ada 2.723 aduan yang 58\% diantaranya kekerasan seksual. Meningkat lagi pada tahun 2013 menjadi 3.339 kasus, dimana $62 \%$ didominasi kejahatanseksual. Kemudian pada 2014 sebanyak 3.762 kasus dengan $52 \%$ diantaranya kekerasan seksual. Oleh karena itu, Presiden kemudian mengeluarkan perintah untuk merevisi kembali Undang-Undang Nomor 35 Tahun 2014 lewat Peraturan Pemerintah Pengganti Undang-Undang (Perppu) Nomor 1 Tahun 2016 yangbelakangan telah menjadi Undang-undang Nomor 17 Tahun 2016. Salah satu maksud pemerintah menerbitkan Peraturan Pemerintah Pengganti Undang-Undang (Perppu) ini adalah untuk kembali memperberat pidana bagi pelaku, untuk mendorong efek jera dari 
pelaku, dan mencegah calon pelaku. Perspektif ini yang masih dipertahankan oleh pemerintah sejak perubahan Pertama atas Undangundang Nomor 32 Tahun 2002 tentang Perlindungan Anak pada tahun2014. Undang-undang Nomor 35 Tahun 2014 tentang Perubahan atas Undang-undang Nomor 23 Tahun 2002 tentang Perlindungan Anak diterbitkan juga berdasarkan pada asumsi bahwa kejahatan seksual terhadap anak bisa dikurangi dengan memperberat ancaman hukuman terhadap para pelakunya. ${ }^{1}$ Dalam Peraturan Pemerintah Pengganti Undang-Undang (Perpu) Nomor 1 Tahun 2016 yang telah disahkan menjadi Undang-undang Nomor 17 Tahun 2016 Tentang Perubahan Kedua Atas Undang-Undang Nomor 23 Tahun 2002 Tentang Perlindungan Anak tersebut merevisi Pasal 81 danPasal 82 dengan pemberatan dan penambahan hukuman bagi pelaku kekerasan seksual pada anak. Pemberatan berupa ancaman penjara sampai 20 tahun, pidana seumur hidup, hingga hukuman mati. Adapun penambahan hukuman bagi para terpidana berupa publikasi identitas pelaku, pemasangan alat deteksi elektronik, hingga dikebiri melalui suntikan kimia.

Disahkannya Undang-undang Nomor 17 Tahun 2016 Tentang Perubahan Kedua Atas UndangUndang Nomor 23 Tahun 2002 Tentang Perlindungan Anak tentunya menimbulkan pro dan kontra. Ada yang mendukung dengan alasan

1 Supriyadi Widodo Eddyono Et. All, Ancaman Overkriminalisasi, dan Stagnansi Kebijakan Hukum Pidana Indonesia : Laporan kejahatan seksual saat ini sudah menjadi kejahatan yang luar biasa sehingga perlu aturan yang khusus. Namun ada yang kontra, dengan alasan tindakan kebiri kimia tersebut melanggar kesepakatan internasional tentang Hak Asasi Manusia, yang telah menyatakan bahwa negara tidak boleh menghukum manusia dengan cara yang merendahkan hak asasi dan nilai kemanusiaan.

Dari uraian latar belakang diatas akan dijelaskan mengenai bagaiman hukuman kebiri kimia daklam perspektif HAM

\section{METODE}

Peneltian ini difokuskan pada penelitian hukum normative karena mengkaji dan emnaganalisi berbagai peraturan perundang-undangan. Penelitian ini menggunakan pendekatan perundang-undangan. Alat pengumpul bahan dalam penelitian ini dilakukan dengan cara mengumpulkan keseluruhan bahan hukum yang relevan dengan masalah yang diteliti melalui studi dokumen dengan tahapan inventarisasi, sistematisasi, sinkronisasi dan harmonisasi berbagai dokumen hukum yang terkait.

\section{HASIL DAN PEMBAHASAN}

Sepanjang sejarah peradaban manusia, kebiri dilakukan dengan berbagai tujuan. Victor $T$ Cheney dalam A Brief History of Castration 2nd Edition tahun 2006, menyatakan, kebiri sudah dilakukan di Mediterania

Situasi Hukum Pidana Indonesia 2016 dan Rekomendasi di 2017, Institute for Criminal Justice Reform (Icjr), 2017, hlm. 15. 
Timur pada 8.000-9.000 tahun lalu. Tujuannya, agar ternak betina lebih banyak dibandingkan yang jantan. Tak ada catatan pasti kapan kebiri dilakukan pada manusia. Namun, di Mesir, pada 2.600 sebelum Masehi (SM), budak yang dikebiri berharga lebih tinggi karena dianggap lebih rajin dan patuh kepada majikannya. Tindakan serupa ditemukan pada budak di Yunani sekitar 500 SM, penjaga harem raja di Persia, serta bendahara dan sejumlah pejabat kekaisaran Tiongkok $^{2}$. Di era modern, tujuan pengebirian lebih beragam, mulai dari usaha mendapat suara soprano pada anak laki-laki di Italia hingga upaya menghindarkan perbuatan tak bermoral di beberapa agama. Kebiri juga dilakukan untuk mengurangi orang dengan gangguan fisik dan mental serta populasi kelompok tertentu. ${ }^{3}$

Kebiri memiliki dua pengertian untuk dapat terlaksananya kebiri tersebut yakni :

a. Pengebirian bedah (Surgical Castration) Dilakukan dengan cara mengamputasi organ seks eksternal pemerkosa sehingga membuat pelaku kekurangan hormon testosteron. Kurangnya hormon ini akan banyak mengurangi dorongan seksualnya. Pada masa purba pengibirian cenderung mereka lakukan dengan cara bedah atau kebiri fisik, yaitu melibatkan

${ }^{2}$ M Zaid Wahyudi. Sumber: Kompas, 19 Mei 2014, http://rumahpengetahuan.web.id/suntikkebirimematikan-dorongan-seksual/, diakses pada tanggal 15 juni 2020 pemotongan seluruh alat kelamin pria, baik testis sekaligus penis. Praktik ini sangat berbahaya dan kerap mengakibatkan kematian akibat pendarahan hebat atau infeksi, sehingga dalam beberapa kebudayaan seperti Kekaisaran Byzantium, pengebirian disamakan dengan hukuman mati. Pemotongan hanya testisnya saja mengurangi risiko kematian.

b. Pengebirian Kimia (Chemical Castration) Berbeda denga pengebirian bedah, kebiri kimia memasukkan zat kimia antiandrogen ke tubuh seseorang supaya produksi hormon testosteron di tubuh mereka berkurang. Hasil akhirnya sama dengan kebiri fisik, yakni menghilangkan libido atau hasrat seksual atau kemampuan ereksi. ${ }^{4}$ Di Rusia, kebiri kimia dilakukan dengan menyuntikkan zat depo-provera yang berisi progesteron sintetis. Dengan penambahan hormon wanita ke tubuh pria, maka hasrat seksual yang bersangkutan akan turun.

Dibawah ini adalah Negara-negara yang telah menerapkan hukuman kebiri :

\begin{tabular}{|c|c|c|c|}
\hline $\mathbf{N}$ & $\begin{array}{l}\text { Negar } \\
\text { a }\end{array}$ & $\begin{array}{l}\text { Keteranga } \\
\text { n }\end{array}$ & $\begin{array}{l}\text { Perkembanga } \\
\text { n terbaru }\end{array}$ \\
\hline
\end{tabular}

\footnotetext{
${ }^{3}$ Ibid

4 https://hellosehat.com/mengenal-proseskebiri-kimia/, di akses pada tanggal 8 Juli 2020
} 
Dinamika Sosial Budaya, Vol 22, No. 2, Desember 2020, pp 129-139

p-ISSN: 1410-9859\& e-ISSN: 2580-8524

http://journals.usm.ac.id/index.php/jdsb

\begin{tabular}{|c|c|c|c|}
\hline 1 & $\begin{array}{l}\text { Korea } \\
\text { selata } \\
\text { n }\end{array}$ & $\begin{array}{l}\text { Korea } \\
\text { Selatan } \\
\text { menjadi } \\
\text { negara } \\
\text { pertama di } \\
\text { Asia yang } \\
\text { melegalka } \\
\text { n hukuman } \\
\text { kebiri di } \\
\text { tahun } \\
\text { 2011.5 } \\
\text { Undang- } \\
\text { undang } \\
\text { tersebut } \\
\text { disahkan } \\
\text { pada bulan } \\
\text { Juli tahun } \\
\text { tersebut } \\
\text { dan } \\
\text { mengijinka } \\
\text { n suntikan } \\
\text { kebiri pada } \\
\text { terdakwa } \\
\text { kejahatan } \\
\text { seksual } \\
\text { berusia di } \\
\text { atas } \\
\text { tahun. }\end{array}$ & $\begin{array}{l}\text { hanya dua pria } \\
\text { telah menjalani } \\
\text { hukuman } \\
\text { kebiri. Juga } \\
\text { mendapat } \\
\text { banyak kritik }\end{array}$ \\
\hline 2 & $\begin{array}{l}\text { Inggri } \\
\text { s }\end{array}$ & $\begin{array}{l}\text { ingris telah } \\
\text { sejak lama } \\
\text { menerapka } \\
\mathrm{n} \text { kebiri } \\
\text { kimia. }\end{array}$ & $\begin{array}{l}\text { Sebanyak } 25 \\
\text { narapidana } \\
\text { secara sukarela } \\
\text { melakukan } \\
\text { suntikan ini di } \\
\text { tahun 2014. } \\
\text { kebijakan ini } \\
\text { merupakan } \\
\text { turunan pasca } \\
\text { perang dunia } \\
\text { II, dimana Pada } \\
\text { saat itu, }\end{array}$ \\
\hline
\end{tabular}

${ }^{5}$ Daftar Negara yang Memiliki Hukuman Kebiri, http://health.kompas.com/read/2015/10/23/17000032

\begin{tabular}{|c|c|c|c|}
\hline & & & $\begin{array}{l}\text { tindakan } \\
\text { homoseksual } \\
\text { antara laki-laki } \\
\text { yang masih } \\
\text { ilegal dan } \\
\text { homoseksualita } \\
\text { s secara luas } \\
\text { dianggap } \\
\text { sebagai } \\
\text { penyakit } \\
\text { mental yang } \\
\text { dapat diobati } \\
\text { dengan } \\
\text { pengebirian } \\
\text { kimia }\end{array}$ \\
\hline 3 & $\begin{array}{l}\text { Amer } \\
\text { ika } \\
\text { serika } \\
\text { t }\end{array}$ & $\begin{array}{l}9 \text { negara } \\
\text { bagian, } \\
\text { termasuk } \\
\text { California, } \\
\text { Florida, } \\
\text { Oregon, } \\
\text { Texas, dan } \\
\text { Washingto } \\
\text { n yang } \\
\text { menerapka } \\
\text { n hukuman } \\
\text { kebiri. }{ }^{6}\end{array}$ & $\begin{array}{l}\text { mendapat } \\
\text { banyak } \\
\text { tantangan } \\
\text {,medroksiprog } \\
\text { esteron asetat } \\
\text { (MPA, bahan } \\
\text { dasar sekarang } \\
\text { digunakan } \\
\text { dalam DMPA) } \\
\text { obat ini tidak } \\
\text { pernah } \\
\text { disetujui oleh } \\
\text { FDA untuk } \\
\text { digunakan } \\
\text { sebagai } \\
\text { pengobatan } \\
\text { untuk } \\
\text { pelanggar } \\
\text { seksual }\end{array}$ \\
\hline 4 & Rusia & $\begin{array}{l}\text { Menerima } \\
\text { chemical } \\
\text { castration } \\
\text { untuk } \\
\text { pelaku } \\
\text { kejahatan }\end{array}$ & $\begin{array}{l}\text { Pada Oktober } \\
\text { 2011, parlemen } \\
\text { Rusia } \\
\text { meloloskan } \\
\text { aturan hukum } \\
\text { yang }\end{array}$ \\
\hline
\end{tabular}

3/Daftar.Negara.yang.Memiliki.Hukuman.Kebiri diakses pada tanggal 8 Juli 2020 Wita

${ }^{6}$ ibid 
Dinamika Sosial Budaya, Vol 22, No. 2, Desember 2020, pp 129-139

p-ISSN: 1410-9859\& e-ISSN: 2580-8524

http://journals.usm.ac.id/index.php/jdsb

\begin{tabular}{|c|c|c|c|}
\hline & & $\begin{array}{l}\text { seksual } \\
\text { terhadap } \\
\text { anak. } \\
\text { Undang- } \\
\text { undang } \\
\text { yang } \\
\text { melegalka } \\
\text { n hukuman } \\
\text { kebiri baru } \\
\text { saja } \\
\text { disahkan di } \\
\text { Rusia. Para } \\
\text { penjahat } \\
\text { seksual } \\
\text { yang } \\
\text { Meski } \\
\text { begitu, } \\
\text { seseorang } \\
\text { harus } \\
\text { dinyatakan } \\
\text { benar- } \\
\text { benar } \\
\text { paedofilia } \\
\text { oleh panel } \\
\text { dokter. }\end{array}$ & $\begin{array}{l}\text { mengizinkan } \\
\text { pengadilan } \\
\text { untuk } \\
\text { memerintahkan } \\
\text { hukuman } \\
\text { kebiri kimiawi } \\
\text { terhadap } \\
\text { pelaku } \\
\text { kejahatan } \\
\text { seksual. } \\
\text { Hukuman } \\
\text { tersebut } \\
\text { mengancam } \\
\text { pelaku } \\
\text { kejahatan } \\
\text { seksual yang } \\
\text { menyerang } \\
\text { anak-anak di } \\
\text { bawah usia } 14 \\
\text { tahun. }\end{array}$ \\
\hline 5 & $\begin{array}{l}\text { Mold } \\
\text { ova }\end{array}$ & $\begin{array}{l}\text { Pada } \\
\text { tanggal } 6 \\
\text { Maret, } \\
2012, \\
\text { pemerintah } \\
\text { Moldova } \\
\text { mulai } \\
\text { memberlak } \\
\text { ukan } \\
\text { hukuman } \\
\text { kebiri bagi } \\
\text { pelaku }\end{array}$ & $\begin{array}{l}\text { Namun } \\
\text { hukuman ini } \\
\text { mendapat } \\
\text { kecaman dari } \\
\text { Amnesty } \\
\text { International } \\
\text { dan disebut } \\
\text { perlakuan tidak } \\
\text { manusiawi. } \\
\text { Amnesty } \\
\text { International } \\
\text { menyebut }\end{array}$ \\
\hline
\end{tabular}

\footnotetext{
${ }^{7}$ Ibid

${ }^{8}$ Ini 9 Negara yang Menerapkan Hukuman Kebiri untuk Pelaku Paedofil, http://batamnews.co.id/berita-7495-ini-9-negarayang-menerapkan-hukuman-kebiri-untukpelakupedofil.html, diakses pada tanggal 8 Juli 2020 Wita
}

\begin{tabular}{|c|c|c|c|}
\hline & & $\begin{array}{l}\text { kejahatan } \\
\text { seksual } \\
\text { anak }\end{array}$ & $\begin{array}{l}\text { bahwa setiap } \\
\text { tindak } \\
\text { kejahatan harus } \\
\text { dihukum } \\
\text { dengan cara } \\
\text { yang sesuai } \\
\text { dengan } \\
\text { Deklarasi } \\
\text { HAM } \\
\text { Universal. }{ }^{10}\end{array}$ \\
\hline 6 & $\begin{array}{l}\text { Jerm } \\
\text { an }\end{array}$ & $\begin{array}{l}\text { Pada tahun } \\
1960 \\
\text { dokter } \\
\text { Jerman } \\
\text { digunakan } \\
\text { antiandrog } \\
\text { en sebagai } \\
\text { pengobata } \\
\text { n untuk } \\
\text { seksual } \\
\text { paraphilia. } \\
\text { Di Jerman, } \\
\text { praktek itu } \\
\text { adalah } \\
\text { bagian dari } \\
\text { perawatan } \\
\text { dan bukan } \\
\text { hukuman }\end{array}$ & $\begin{array}{l}\text { Dewan Eropa } \\
\text { mengritik } \\
\text { hukuman } \\
\text { kebiri terhadap } \\
\text { pelaku } \\
\text { kejahatan } \\
\text { seksual di } \\
\text { Jerman. } \\
\text { Komite Anti } \\
\text { Penyiksaan } \\
\text { organisasi } \\
\text { negaranegara } \\
\text { Eropa } \\
\text { mendesak agar } \\
\text { pelaksanaan } \\
\text { hukuman } \\
\text { semacam itu } \\
\text { diakhiri, walau } \\
\text { pun terpidana } \\
\text { bersedia } \\
\text { menerima } \\
\text { hukuman itu } \\
\text { dan hukuman } \\
\text { itu sangat } \\
\text { jarang } \\
\text { diterapkan. }\end{array}$ \\
\hline
\end{tabular}

${ }^{9}$ Ini 9 Negara yang Menerapkan Hukuman Kebiri untuk Pelaku Paedofil, http://batamnews.co.id/berita-7495-ini-9-negarayang-menerapkan-hukuman-kebiri-untukpelakupaedofil.html, diakses pada tanggal 8 Juli 2020 Wita ${ }^{10}$ Ibid 
Mesikpun beberapa negara tersebut di atas sudah memasukkan pasal hukuman atau tindakan/perawatan kebiri dalam hukum pidana mereka, namun dalam banyak kajian, ternyata sulit menerapkannya. Hukum acara yang mengatur mekanisme penerapan pasal tersebut mengalami kesulitan, karena harus melakukan diagonosa lebih dahulu sebelum menerapkannya, karena tidak semua pelaku harus dikebiri, tetapi harus dicek dan diagonosa lebih dahulu kesehatannyanya dan implikasi medisnya. pada paruh abad pertengahan, telah lahir pemikir-pemikir besar, antara lain di benua, eropa dikenal John Locke, De la Montesuieu, Karl Von Savigny, Immanuel Kant, AV, Dicey, dan di dunia islam dikenal Ibnu Khaldum, Syekh Muhmmad Abduh, dan lainnya. Tokoh-tokoh ini menciba menyumbangkan ide-ide dan konsep-konsep pemikiran orisionalitasnya tentang nilai-nilai kemanusiaan sesuai kodrat kemanusiaannya sebagai anugerah Tuhan. Pewacanaan, pengonstruksian dan penormaan penghormatan perlindungan dan penegakan nilai-nilai, harkat dan martabat kemanusiaan sesuai kodratnya sebagai anugerah pemberian Tuhan Yang Maha Esa telah dikonsepsikan dengan istilah Hak Asasi Manusia (Human Right), yang disebutnya juga sebagai hak alamiah (Nature right), hakhak sunatullah, dan oleh Negara disebutnya sebagai hak-hak dasariah (basis rights/fundamental rights). ${ }^{11}$

Hak asasi manusia sebagai anugerah Tuhan Yang Maha Esa, biasa dirumuskan sebagai hak kodratiah yang melekat dimiliki oleh manusia sebagai karunia pemberian Tuhan kepada insan manusia dalam menopang dan mempertahankan hidup dan prikehidupannya di muka bumi. Menurut

${ }^{11}$ Nurul Qomar, "Hak Asasi Manuia dalam Negara Hukum Demokrasi", sinar grafika, Jakarta,hlm. 2-4.

${ }^{12} \mathrm{Ibid}$, hlm. 5.
Marthen Kraile, HAM adalah hak yang bersumber dar Allah, sedangkan Jack Donally, mengatakan bahwa HAM adalah hak yang bersumber dari hukum alam, tetapi sumber utamanya dari Allah. Sedang dalam kaitannya dengan hukum, Mansyur Effendy mengatakan bahwa hukum dan HAM merupakan satu kesatuan yang sulit untuk dipisahkan, keduanya seperti dua sisi dalam satu mata uang. Apbila suatu bangunan hukum dibangun tanpa Hak Asasi Manusia yang merupakan pengawal bagi hukum dalam merealisasi perwujudan nilai-nilai keadilan kemanusiaan. Sebaliknya apabila HAM dibangun tanpa didasarkan atas suatu komitmen hukum yang jelas, maka HAM tersebut hanya akan menjadi bangunan yang rapuh dan mudah untuk disimpangi. Artinya hukum harus berfungsi sebagai instrumentarium yuridis, sarana dan atau tool memperhatikan penghormatan terhadap prinsip-prinsip dalam HAM. ${ }^{12}$

Sebagaimana diketahui, bahwa hampir semua perjanjian internasional menganut prinsip-prinsip yang nanti akan diuraikan oleh penulis, Adapun prinsipprinsip itu adalah: ${ }^{13}$

a. Prinsip kesetaraan

Sesuatu yang sangat fundamental dari hak asasi manusia kontemporer adalah ide yang meletakan semua orang terlahir bebas dan memiliki kesetaraan dalam hak asasi manusia. Kesetaraan mensyaratkan adanya perlakuan yang setara, dimana pada situasi sama harus diperlakuka dengan sama, dan dengan perdebatan, dimana pada situasi yang berbeda diperlakukan dengan berbeda pula.

b. Prinsip diskriminasi

${ }^{13}$ Rhona K.M Smith et. Al., "Hukum Hak Asasi Manusia", Cetakan Pertama, Pusat Studi Hak Asasi Manusia Universitas Islam Indonesia, Yogyakarta, 2008, hlm. 39-41. 
Diatas telah dijelaskan tentang prinsip kesetaraan, maka pelarangan terhadap diskriminasi adalah merupakan bagian penting juga dalam prinsip kesetaraan itu. jika semua orang setara, maka seharusnya tidak ada perlakuan yang diskriminatif. Sebab jika merujuk pada pengertian diskriminasi adalah kesengajaan perbedaan perlakuan dari perlakuan yang seharusnya sama atau setara.

Ada dua macam diskriminasi, yakni diskriminasi langsung dan tidak langsung. Diskriminasi langsung adalah ketika seorang baik langsung maupun tidak langsung diperlakukan berbeda (less favourable) dari pada lainnya. Sedangkan diskriminasi tidak langsung muncul ketika dampak dari hukum atau dalam praktek hukum merupakan diskriminasi, walaupun hal itu tidak ditujukan untuk tujuan diskriminasi. Sebagai contoh misalkan pembatasan pada hak kehamilan jelas akan berpengaruh lebih besar kepada perempuan dari pada laki-laki. Selain itu, hukum hak asasi manusia internasional telah memperluas alasan diskriminasi.

Deklarasi Universal Hak Asasi Manusia (DUHAM) menyebutkan beberapa alasan diskriminasi antara lain ras, warna kulit, jenis kelamin, bahasa, agama, pendapat politik atau opini lainnya, nasional atau kebangsaan, kepemilikan akan suatu benda (property), kelahiran atau status lainnya. Semua hal itu merupakan alasan yang tidak terbatas dan semakin banyak pula instrument yang memperluas alasan diskriminasi termasuk di dalamnya orientasi seksual, umur dan cacat tubuh.

c. Kewajiban Positif untuk Melindungi Hak-Hak Tertentu.
Menurut hukum hak asasi manusia internasional, suatu negara tidak boleh secara sengaja mengabaikan hak-hak dan kebebasan. Sebaliknya, negara diasumsikan memiliki kewajiban positif untuk melindungi secara aktif dan memastikan terpenuhinya hak-hak dan kebebasan-kebebasan. Untuk kebebasan berekspresi, sebuah negara boleh memberikan kebebasan dengan sedikit pembatasan yang diatur secara hukum. Untuk hak hidup, negara tidak boleh menerima pembatasan yang pasif, negara wajib membuat aturan hukum dan mengambil langkah-langkah guna melidungi hak dan kebebasan secara positif yang dapat diterima oleh negara. karena alasan inilah, maka Negara berkewajiban membuat aturan hukum yang melarang pembunuhan untuk mencegah aktor non negara melanggar hak untuk hidup. Penekannanya adalah bahwa negara harus bersifat proaktif dalam menghormati hak untuk hidup dan bukan bersifat pasif. Contoh misalnya hak untuk hidup itu sendiri dan pelarangan penyiksaan. Negara tidak boleh mengikuti kesalahan dari negara lain yang melanggar ketentuan hak untuk hidup atau melanggar larangan penyiksaan. Suatu negara tidak boleh membantu negara lain untuk menghilangkan nyawa seseorang atau melanggar larangan penyiksaan.

Dari gambaran prinsip-prinsip yang telah diuarikan diatas, poin penting yang dapat penulis garis bawahi dari prinsip adalah berkaitan dengan kewajiban positif untuk melindungi hak-hak tertentu yakni hak hidup dan larangan atas suatu penyiksaan. Penyiksaan dipandang secara paling serius oleh komunitas internasional, sebab penyiksaan adalah salah satu intrumen penting internasional dalam perlindungan hak asasi manusia. Pelarangan terhadap penyiksaan ini tidak dapat dikurangi dalam 
keadaan apapun (non derogable) dan melakukan penyiksaan adalah merupakan kejahatan internasional menurut statuta Roma Mahkamah Pidana Internasional. ${ }^{14}$ Kewajiban penguasa negara untuk menghormati hak untuk bebas dari penyiksaan, sebagaiman hal itu diisyaratkan dalam Deklarasi Umum Hak Asasi Manusia PBB (DUHAM-PBB) dalam Pasal 5 yang menyebutkan "tiada seorang juapun boleh dianiaya atau diperlakukan secara kejam, dengan tidak mengingat kemanusiaan atau jalan perlakuan atau hukuman yang menghinakan (no body shall be subjected to acts of torture nor to cruel, in human and degrading punishment)". ${ }^{15}$

Agenda PBB tentang Ham telah menghasilkan beberapa piagam penting, antar lain Deklarasi Universal Hak Asasi Manusia Tahun 1948 (Declration of Human Rights). Konvenan Internasional Hak sipil dan Politik Tahun 1966. Konvenan Internasional Ekonomi, Sosial dan Budaya Tahun 1966. Deklarasi Wina Tahun 1993 yang menghasilakan tercapainya suatu consensus antara Negara-negara barat dan Negara non barat tentang universalisme Hak Asasi Manusia (sifat universal hak asasi manusia), meskipun kemungkinan terjadi perbedaan dalam implementasinya sesuai dengan keadaan dan kekhasan bagi masingmasing Negara anggota PBB. pada tahun 1993 lahir viena declration and programme of action di wina. Pada tahun 2002 telah didirikan Mahkamah Pidna Internasional (International Criminal Court) (ICC) yang kewenangannya mengadili kasus-kasus pelanggaran terhadap HAM berat seperti kejhatan kemanusiaan, genosida, dan kejahatan perang.

${ }^{14}$ Ibid hlm 154

${ }^{15}$ Artidjo Alkostar et. Al., Penyiksaan Dalam Anarki Kekuasaan. Fakultas Hukum Universitas Islam Indonesia, Yogyakarta, 1996, hlm 5
Selain dari tersebut di atas, di Negaranegara non barat telah pula lahir berbagai dokumen penting tentang HAM, antara laintentang African (Banjul) Charter on Human and people's right pada tahun 1981 di afrika. Pada tahun 1990 lahir cairo declaration on human rights in islam di Mesir. Pada tahun 1991 lahir Singapore white paper on shared values di Singapore. ${ }^{16}$

Segala instrument hukum internasional tentang HAM telah penulis uraikan di atas, dan konsekuensi logisnya adalah Negara dan pemerintah sebagai penanggung jawab utama terimplementasinya perlindungan dan penegakan HAM termasuk Indonesia dituntut untuk segera meratifikasi konvenankonvenan PBB yang berkenaan dengan HAM dan meletakannya dalam undang-undang serta mereview dan membentuk beberapa perundang-undangan yang mengakomodir nilai-nilai tentang HAM. Untuk itu Indonesia telah meratifikasi bebrapa konvenan PBB berkenaan dengan HAM antara lain tentang convention against torture and other cruel, inhuman or degrading treatment or punishment (konvensi menentang penyiksaan dan perlakuan atau penghukuman lain yag kejam, tidak manusiawi, atau merendahkan martabat manusia) yang ditetapkan dengan Undang-undang RI Nomor 5 Tahun 1998, selanjutnya ditetapkan beberapa peraturan perundang-undangan antara lain Undangundang nomor 39 Tahun 1999 tentang HAM, Undang-undang nomor 26 tahun 2006 tentang pengadilan HAM dan puncaknya setelah dilakukan amandemen UUD Tahun 1945. ${ }^{17}$

Selain isntrumen internasional konvensi menentang penyiksaan oleh PBB,

\footnotetext{
${ }^{16}$ Nurul Qomar, Hak Asasi Manuia dalam Negara Hukum Demokrasi, sinar grafika, Jakarta hlm 3-4

${ }^{17}$ Ibid, hlm. 5.
} 
di Indonesia sendiri telah ada suatu dokumen nasional tentang larangan penjatuhan hukuman yang kejam. Hal itu disebutkan dalam konstitusi Indonesia sebagai berikut $:^{18}$

a. Pasal 11 UUD Sementara 1950 : Tiada seorang juapun akan disiksa ataupun diperlakukan atau dihukum secara ganas, tidak mengenal perikemanusiaan atau menghina.

b. Pasal 11 dari Konstitusi RIS : Mengatur tentang hak untuk tidak disiksa ataupun diperlakukan atau dihukum secara ganas, tidak mengenal perikemanusiaan atau dihina.

c. Pasal 28 I UUD 1945 hasil amandemen menempatkan hak untuk hidup dan untuk tidak disiksa sebagai hak asasi manusia yang tidak dapat dikurangi dalam keadaan apapun.

d. Pasal $28 \mathrm{G}$ hasil amandemen antara lain menyebutkan bahwa setiap orang berhak atas perlindungan diri pribadi, kehormatan dan martabat, dan bebas dari penyiksaan dan perlakuan yang merendahkan derajat martabat manusia.

Pengaturan terhadap perlindungan hak asasi manusia ini kemudian diatur lagi lebih spesifik dalam Undang-Undang Nomor 39 Tahun 1999 tentang Hak Asasi Manusia. Undang-undang ini sering disebut sebagai angin segar bagi jaminan perlindungan hak asasi manusia di Indonesia, meskipun UUD 1945 masih dianggap cukup menjamin perlindungan hak asasi manusia. UndangUndang Nomor 39 tahun 1999 ini memberi pengaturan secara terperinci tentang pemajuan dan perlindungan hak asasi manusia. Tidak hanya menentang penyiksaan, ketentuan undang-undang ini lebih spesifik lagi mengatur tentang hak

${ }^{18}$ Munir Fuady dan Sylvia Laura L. Fuady, "Hak Asasi Tersangka Pidana", Prenada Media Group, Jakarta, 2015, hlm. 132-133 berkeluarga dan melanjutkan keturunan. Pasal 10 dalam undang-undang ini menyatakan bahwa "setiap orang berhak membentuk suatu keluarga dan melanjutkan keturunan melalui perkawinan yang sah yang hanya dapat berlangsung atas kehendak kedua calon suami dan istri yang bersangkutan sesuai dengan peraturan perundang-undangan, dalam hal adalah Undang-Undang Nomor 1 Tahun 1974 tentang Perkawinan". sama seperti halnya dinyatakan dalam Pasal 28B ayat (1) UUD 1945 hasil amandemen ke-2. ${ }^{19}$

Melihat dari instrument-instrumen hukum internasional maupun nasional jelas memperlihatkan bagaimana sanksi tindakan kebiri dalam uu pelindungan anak nomor 16 tahun 2017 sangat berlawanan dengan semangat menjujung HAM, seperti yang ada dalam Majelis Umum PBB melalui sebuah resolusi 39/46 mengesahkan sebuah konvensi guna melindungi hak-hak manusia, khusunya hak untuk tidak disiksa dan diperlakukan kejam atau hukuman yang merendahkan martabat kemanusiaan. Jelas sekali di dalam pembukaan konvensi itu, bahwa perlindungan terhadap penyiksaan, perlakuan kejam dan merendahkan martabat manusia adalah merupakan tujuan dari diadakannya konvensi tersebut. Selain itu juga dalam instrument hukum nasional telah diatur dalam Pasal $28 \mathrm{G}$ hasil amandemen antara lain menyebutkan bahwa setiap orang berhak atas perlindungan diri pribadi, kehormatan dan martabat, dan bebas dari penyiksaan dan perlakuan yang merendahkan derajat martabat manusia.

Pengaturan terhadap perlindungan hak asasi manusia ini kemudian diatur lagi lebih

\footnotetext{
${ }^{19}$ Rhona K.M Smith et. Al, Op.,Cit, hlm. 258.
} 
spesifik dalam Undang-Undang Nomor 39 Tahun 1999 tentang Hak Asasi Manusia. Undang-undang ini sering disebut sebagai angin segar bagi jaminan perlindungan hak asasi manusia di Indonesia, meskipun UUD 1945 masih dianggap cukup menjamin perlindungan hak asasi manusia. UndangUndang-undang Nomor 39 tahun 1999 ini memberi pengaturan secara terperinci tentang pemajuan dan perlindungan hak asasi manusia.

\section{KESIMPULAN}

Hukuman kebiri kimia dapat dikualifikasi sebagai bentuk penghukuman yang keji dan tidak manusiawi yang dengan demikian tidak sesuai dengan semangat dunia internasioanal untuk menghilangkan hukuman yang merendahkan harkat dan martabat manusia, selain itu hukuman kebiri juga tidak sesuai dengan konstitusi, peraturan perundangundangan lainya seperti undang-undang nooer 39 tahun1999 tentang Hak Asasi manusia dan komitmen Indonesia dalam bidang hak asasi manusia.

\section{DAFTAR PUSTAKA}

Artidjo Alkostar Et. All. , (1996). Penyiksaan Dalam Anarki Kekuasaan. Yogyakarta, Fakultas Hukum Universitas Islam Indonesia.

Nurul Qomar. (2013). Hak Asasi Manuia dalam Negara Hukum Demokrasi, Jakarta, Sinar Grafika, Munir Fuady dan Sylvia Laura L. Fuady, (2015). Hak Asasi Tersangka Pidana, Jakarta, Prenada Media Group.

Rhona K.M Smith Et. All. (2008). Hukum Hak Asasi Manusia, Yogyakarta, Pusat Studi Hak Asasi Manusia Universitas Islam Indonesia.
Supriyadi Widodo Eddyono Et. Alll (2017). Ancaman Overkriminalisasi, dan Stagnansi Kebijakan Hukum Pidana Indonesia : Laporan Situasi Hukum Pidana Indonesia 2016 dan Rekomendasi di 2017, Institute for Criminal Justice Reform (Icjr).

19 Mei 2014,

http://rumahpengetahuan.web.id/suntikkebirimematikan-dorongan-seksual/, diakses pada tanggal 15 juni 2020

https://hellosehat.com/mengenalproses-kebiri-kimia/, di akses pada tanggal 8 Juli 2020

Daftar Negara yang Memiliki Hukuman Kebiri, http://health.kompas.com/read/2015/10/23/1 70000323/Daftar.Negara.yang.Memiliki.Hu kuman.Kebiri diakses pada tanggal 8 Juli 2020 Wita

Ini 9 Negara yang Menerapkan Hukuman Kebiri untuk Pelaku Paedofil, http://batamnews.co.id/berita-7495-ini-9negara-yang-menerapkan-hukuman-kebiriuntuk-pelakupedofil.html, diakses pada tanggal 8 Juli 2020 Wita 